\title{
Substantive Model of Teacher Pedagogical Sustainable Profession as An Effort to Improve The Quality of PBI Based on Text and Character in Junior High School and MTs
}

\author{
Nur Fajar Arief \& Akhmad Tabrani \\ Universitas Islam Malang \\ nfarief@unisma.ac.id, tabrani@unisma.ac.id
}

$\begin{array}{ll}\text { Article History } & \text { Received : August } 7^{\text {th }} 2020 \\ & \text { Revision : October } 11^{\text {th }} 2020 \\ & \text { Publication : November } 30^{\text {th }} 2020\end{array}$

\begin{abstract}
:
Sustainable professional development of pedagogic teachers is a strategic effort to improve the competence and performance of teachers in carrying out their duties and functions as planners, implementers, and evaluation of learning in the classroom. This research aims to examine the improvement of innovative, creative, adaptive, and productive quality of PBI based on Indonesian text and character through the SKBP model of teachers in junior high schools and MTs. This research was conducted using qualitative approach with survey type. The research subjects were PBI teachers in 6 junior high schools and MTs selected research target locations by using random patterns of strata. Descriptive data of 5 research objects obtained by researchers as a key instrument with interview techniques, questionnaires, and focused observations. Data analysis was carried out using a flow model during the study. The development models used are R2D2 model: Recursive, Reflective Instructional Design and Development and Oxford training strategy model. The assessment of the effectiveness of the SKBP model was carried out using a qualitative approach with the type of class action research of the Kemmis and Taggart models. The research subjects were PBI teachers and grade VIII students at 6 junior high schools in Malang districts and cities. Further data analysis is done descriptively, including (1) improvement of pbi process based on Indonesian text and character using SKBP model and (2) improvement of PBI results based on Indonesian text and character using SKBP model.
\end{abstract}

Keywords: substantive, pedagogical, text, Indonesian model

\section{Introduction}

Sustainable professional development of pedagogic teachers is a strategic effort to improve the competence and performance of teachers in carrying out their duties and functions as planners, implementers, and evaluation of learning in the classroom. Law No. 14 of 2005 confirms that competence is a set of knowledge, skills, and behaviors that must be possessed, imagined and mastered by teachers in carrying out professional tasks (Depdiknas, 2005). Performance is a demonstration of teachers' 
work in implementing pedagogical, professional, social, and personality competencies. Pedagogic is the competence of managing the learning of learners. Depdiknas (2003) stated that this competency includes understanding the insights or foundations of education, understanding learners, developing curriculum and learning tools, designing learning, implementing educational and fun learning, utilizing learning technology, evaluating learning, and developing learners in actualizing their potential.

Education reform mandated by Law No. 20 of 2003 on the National Education System, Law No. 14 of 2005 on Teachers and Lecturers, and Government Regulation No. 32 of 2013 on National Standards of Education demand a balance of quality between professionalism and teacher careers. Teachers in this case are professional educators with the primary task of educating, teaching, guiding, directing, training, assessing, and educating learners on the early childhood education pathways of formal education, primary education, and secondary education. Teacher professional development includes the development of pedagogical, professional, social, and personality competencies. Meanwhile, career development includes assignments, promotions, and promotions.

The new paradigm shift in Indonesian language (and literary) learning in junior high schools and MTs is characterized by several characteristics, namely (1) language should be viewed as text, not merely a collection of words or linguistic rules, (2) the use of language is the process of selecting forms of language to express meaning, (3) language is functional, namely the use of language that can never be released from context because the form of language used reflects the idea of , the attitudes, values, and ideologies of its users, and (4) language is a means of forming human thinking abilities, and such a way of thinking is realized through the structure of the text (Wiratno, 2013).

The objective condition of Indonesian language learning currently shows the phenomenon of professionalism, among others: (1) Indonesian teachers who served in smp / MTs (also in elementary and high school / ma) are not in the background of education in accordance with the provisions and fields of study they foster, (2) Indonesian teachers who have low scientific competencies and professionalism and concerns, (3) Indonesian teachers who are less motivated and motivated to empower themselves, develop self-professionalism and develop their knowledge continuously and continuously even though quite a number of Indonesian teachers are very diligent in participating in educational programs, (4) Indonesian teachers are less able to write scientific works in the field of learning, find simple and appropriate technology in the field, make learning aids, and or create artworks, and (5) Indonesian teachers need the development of self-awareness, and the ability to attend meetings to develop the profession (Paryono, 2016)

Fenomena di atas diperkuat dengan hasil uji kompetensi guru tahun $2011 \mathrm{di}$ Jawa Timur terhadap kemampuan pedagogik menunjukkan rerata pencapaian 45.52, sedangkan kemampuan profesional menunjukkan rerata pencapaian 48,45 (Arief, 
2013). Pada tahun 2012 hasil uji komptensi guru gabungan antara kompetensi pedagogik dan profesional yakni 47,89 (Arief, 2013a). Khusus guru bahasa Indonesia rerata pencapaiannya yakni 48,87 (Arief, 2013b). Berdasarkan uraian tersebut, penelitian tentang model SKBP guru yang dapat meningkatkan mutu PBI berbasis teks dan karakter keindonesiaan di SMP dan MTs sangat strategis untuk dilakukan. Model SKBP guru yang dikembangkan ini berpotensi untuk meningkatkan kompetensi pedagogik guru dalam merencanakan, melaksanakan, dan mengevaluasi PBI di SMP dan MTs. Dengan demikian, tercipta pembelajaran PBI yang inovatif dan adaptif di dalam kelas dalam rangka pencapaian tujuan pembelajaran bahasa Indonesia sebagaimana dalam kurikulum nasional BI.

The above phenomenon is reinforced by the results of teacher competency test in 2011 in East Java to pedagogical ability showing an average achievement of 45.52, while professional ability shows an average achievement of 48.45 (Arief, 2013). In 2012, the results of a joint teacher competency test between pedagogical and professional competencies were 47.89 (Arief, 2013a). Especially for Indonesian teachers, the average achievement is 48.87 (Arief, 2013b). Based on the description, research on teacher SKBP model that can improve the quality of PBI based on text and Indonesian character in SMP and MTs is very strategic to do. The teacher SKBP model developed has the potential to improve the pedagogical competencies of teachers in planning, implementing, and evaluating PBI in junior high schools and MTs. Thus, creating innovative and adaptive PBI learning in the classroom in order to achieve the objectives of Indonesian language learning as in the BI national curriculum.

\section{METHOD}

This research uses qualitative approach. The type of research used is survey. Therefore, the type of data collected is verbal type and data analysis is done using content analysis procedure. In terms of design, this research will use descriptive design. Descriptive design will be used to achieve research objectives related to the needs of the SKBP model based on the current objective conditions of PBI in SMP and MTs, including innovative learning models, creative learning media, adaptive learning evaluation, productive learning implementation design, and publication of research results or ideas of PBI learning based on text and Indonesian character in SMP and MTs districts and cities of Malang. The research subjects were 6 PBI teachers and grade VII students who were selected by using random pattern ofstrata, including SMPN 5 Malang City, SMPN 12 Malang City, Smp Santa Maria Malang City, Integrated MTs Ar-Raihan Kab. Malang, MTsN 1 Lawang Kab. Malang, and MTsN Kepanjen Kab. Malang. Descriptive data of 5 research objects obtained by researchers as a key instrument with interview techniques, questionnaires, and focused observations. Instruments used in this study include: observation checklist, observation notes in class (documents, questionnaires, portfolios). Check observational checks and observation notes to 
record learning activities and to record the results of interviews and expert consultations; documents for model data, media data, evaluation data and design data; questionnaires to record objective condition data of model needs, model assessment from Indonesian language education experts, teachers and students as model users; portfolio to record the development of learning processes and results after applying the SKBP model of teachers in text-based PBI and Indonesian characters in smp and MTs.

Data analysis techniques used to process this research data is quantitative and qualitative descriptive data analysis. Expert test data and small group test SKBP PBI model based on tesks and Indonesian character from the questionnaire are analyzed percentage and explained qualitatively. Field test data / user test in the form of lecture process in the development environment is analyzed with qualitative data analysis of flow model (Milles \& Huberman, 1992). Analysis activities, including data reduction, data presentation, and inferent or verification withdrawal. Data reduction activities include classifying and encoding according to the type of data. Presentation of data in the form of descriptions, tables, diagrams, drawings or other visual shapes. The data presented is verified, interpreted, and inferred. Data analysis targets include observation level, description level, and exoplanet level. At the observation level the data is selected, categorized and coded. At the description level and data are presented in units of patterns, units of events, units of inclination, or units of meaning. At the explanation level the analysis is directed at the effectiveness of the trial. The result of analysis of qualitative trial data is used to revise the model product, tailored to the needs. Similarly, qualitative data in the form of assessments, comments, responses and inputs of experts and team members are utilized to revise model products as needed.

\section{RESULT AND DISCUSSION}

\section{SKPB Model Needs Innovative Learning Models}

Five indicators of the need for innovative learning model objects include (1) mastery of the basics of text-based productive language skills, (2) mastery of the basics of text-based receptive language skills, (3) development of substantive mastery of innovative text-based Indonesian language learning models, (4) development of substantive mastery of innovative Character-based Indonesian language learning models to Indonesia, and (5) the use of innovative text-based and character-based learning models to Indonesian.

On the first indicator, with the question of whether it is necessary to increase the substantive mastery of the basics of text-based productive Indonesian language skills in accordance with the applicable curriculum, a total of $80 \%$ of respondents stated that it is necessary and $20 \%$ of respondents stated it was necessary. The second indicator, with the question of whether it is necessary to increase the substantive mastery of the basics of text-based receptive Indonesian language skills in accordance with the applicable curriculum, a total of $60 \%$ of respondents stated it was necessary and $40 \%$ 
of respondents stated it was necessary. This indicates that subsistence strengthening the basics of language skills is indispensable to teachers. It appears that productive language skills are more dominantly needed, it is possible because the basic competencies of Indonesian language in SMP / MTs based on the 2013 curriculum that is being implemented more learning activities producing text.

The basics of receptive language skills that are generally needed by BI teachers in junior high school are listening types and techniques as well as types and reading techniques. Because each type and technique is not widely known by the teachers. Bi teachers in junior high school think that listening in junior high school is the same as listening to a text and recording or mentioning the results of the listening. Reading is also done by students in the classroom independently and then answering questions. So it needs to be explained by an understanding of the nature, characteristics, types, and techniques of reading.

On the third indicator, with the question of whether innovative learning model basic materials are needed for text mastery in Indonesian language learning, overall or $100 \%$ of responses are indispensable. The fourth indicator with the question of whether the basic materials of innovative learning models are needed for the development of Indonesian values, norms, and behaviors, a number of $60 \%$ stated indispensable and $40 \%$ stated quite necessary. While the fifth indicator, with a statement whether the Indonesian language learning that has been done so far has been in accordance with the characteristics and synths of innovative learning models for the development of mastery of texts and values, norms, and behavior to Indonesian as much as $50 \%$ stated very appropriate and the other $50 \%$ stated quite appropriate. The important thing that can be known is that factually Indonesian teachers SMP / MTs need strengthening the substance of science about the methodology of the learning model that concerns the delivery of content and management of the classroom.

The learning content delivery models required by teachers include problembased learning synths, project-based learning, and discovery-based learning. The required class management model for further strengthening includes contextual methods with various techniques and cooperative methods with various techniques. Teachers need an understanding of how to integrate these two types of learning models in learning steps with scientific approaches.

Substantive material of pedagogical competencies on the fundamentals of Indonesian values, norms, and behavior development in innovative learning models is needed by teachers. The necessary material emphasis is related to the planting of Indonesian characters both through the presented text material and Indonesian language learning activities in the classroom. Both of these are part of indirect learning that psychologically becomes a student learning experience. However, the selection of text material containing Indonesian character content becomes an important thing for teachers to do contextually since the beginning of the learning plan. Similarly, student 
activities that are reflected in the choice of classroom management techniques can also build the character of Indonesia in the students.

\section{SKPB Model Needs Creative Learning Media}

Five indicators of the need for creative learning media objects include (1) development of text-based Indonesian language learning materials, (2) development of substantive mastery of text-based creative Indonesian language learning media, (3) development of substantive mastery of creative Indonesian language learning media based on character to Indonesia, (4) development of creative Indonesian language learning media based on character to Indonesia, and (5) development of creative Indonesian language learning media based on text and Indonesian characters.

On the first indicator, with the question of whether Indonesian learners have been able to learn the text well based on the material that has existed so far, a number of $60 \%$ of respondents expressed good enough and $40 \%$ of respondents expressed disuse not well. The second indicator, with the question of whether creative media basic materials are needed for the mastery of text in Indonesian language learning, a total of $85 \%$ of respondents stated that it is necessary and $15 \%$ of respondents said it was necessary. The third Indicator, with the question of whether it is necessary basic material of creative media for the development of values, norms, and behavior to Indonesian, a number of $15 \%$ of respondents stated very necessary and $85 \%$ of respondents said it was necessary. This indicates that substitutive strengthening of the basics of creative media in Indonesian language learning is very necessary for teachers to increase students' mastery of the text being processed. Creative media as a messaging tool needed by teachers as a strengthening of pedagogical substance includes understanding, type, characteristics, development, and utilization of ICT-based media. Through this ICT-based creative media in addition to increasing the motivation and excitement of students learning in Indonesian language learning, it is also expected to improve The Indonesian language text skills in accordance with each basic competency that must be mastered. The fourth indicator, with the question of whether students have utilized creative Indonesian language learning media in order to achieve text comprehension and obtaining Indonesian values, norms, and behaviors of $15 \%$ stated quite well and $85 \%$ of respondents expressed poor. The fifth indicator, with the question of what if students are provided with creative language learning media Indonesia creative text-based and at the same time character-based number of $70 \%$ of respondents stated that it is necessary and 30\% of respondents stated is enough necessary. This shows that students have not fully obtained Indonesian values, norms, and behaviors in Indonesian language learning in SMP/MTs. This is very possible because student learning activities are dominated only by the use of student books. Variations in Indonesian character content with contextual principles are necessary for the formation of student personalities based on local wisdom owned by the 
surrounding environment.

Planning, development, and utilization of ICT-based creative media is very necessary for Indonesian teachers in SMP/MTs. ICT-based which is intended to include integrating all learning components ranging from basic competencies, indicators, objectives, materials, learning steps according to the choice of models and techniques, and evaluation in one creative media. Integration is done by utilizing various ICT software such as android, flash, $i$-spring, exe, etc

\section{SKPB Model Needs Adaptive Learning Evaluation}

Three indicators of the need for adaptive learning evaluation objects include (1) the development of substantive material evaluation of adaptive learning of Indonesian language based on text and character to Indonesia, (2) the development of adaptive learning evaluation of Indonesian language based on text and character to Indonesia, and (3) the implementation of adaptive learning evaluation of Indonesian language based on Indonesian character.

On the first indicator, with the question of whether it is necessary to strengthen the substantive evaluation of adaptive learning of Indonesian language based on Indonesian texts and characters, a total of $70 \%$ of respondents stated that it is necessary and $30 \%$ of respondents stated that it is quite necessary. This shows that Indonesian teachers in SMP/MTs need adequate reinforcement of conceptual material for the evaluation of Indonesian language learning in accordance with the current revised 2013 edition of the curriculum. The second indicator, with the question of whether the evaluation of Indonesian language learning that has been compiled so far has been in accordance with KD, indicators, and objectives of text-based Indonesian language learning and strengthening the planting of Indonesian characters, a number of $85 \%$ of respondents stated quite appropriate and $15 \%$ of respondents expressed less appropriate. The lack of respondents who stated that it is appropriate indicates the need for teacher implementation of learning evaluation planning that meets the characteristics of validity and reliability. These two characteristics are part of the adaptability of evaluation of Indonesian language learning in SMP/MTs. Adaptive which is intended to be (a) conformity between the form of the question with the core competencies and the basis of text-based learning, (b) the suitability between the type of problem and the text-based learning indicator, and (c) the suitability between the assessment rubric and the purpose of text-based learning.

The third indicator, with the question of whether the evaluation of learning that has been compiled so far can well reflect the mastery of knowledge and skills in accordance with $\mathrm{KI}, \mathrm{KD}$, indicators, and the purpose of learning Indonesian languagebased texts and strengthening the planting of Indonesian character, a number of $40 \%$ of respondents stated quite well and $60 \%$ of respondents expressed less well. This indicates that there is a need to increase understanding of the quantity and quality of 
the problem with its various variations. The quantity of questions in this case concerns the number of questions and the scope of indicators and learning objectives to be measured. The quality of the question relates to the suitability and reliability of test item items, including the development of student independence during the evaluation of learning.

\section{SKPB Model Needs Productive Learning Design}

Four indicators of the need for productive learning design objects include (1) development of character-based Indonesian language learning materials to Indonesia, (2) development of substantive materials for productive learning design of Indonesian language based on Indonesian text and character, (3) development of productive learning design of Indonesian language based on Indonesian text and character, and (4) implementation of productive learning design of Indonesian language based on Indonesian character.

On the first indicator, with the question of whether students at the time of learning Indonesian language has been able to obtain the character of Indonesia well from the material that has existed so far, a number of $60 \%$ of respondents expressed good enough and $30 \%$ of the respondents expressed no good. This gives an idea that Indonesian teachers in SMP/MTs want to be more able to develop learning materials with additional content of Indonesian character for students. Substantive strengthening of pedagogic in this case is in strengthening the selection of character-laden texts developed from contextual learning resources of students.

The second indicator, with the question of whether it is necessary to strengthen the substantive design of the implementation of Indonesian language-based text and Indonesian character learning a number of $85 \%$ of respondents stated that it is urgently needed and 15\% not enough is needed. This provides an overview that the basic material of drafting learning based on the curriculum 2013 revised edition is very necessary for Indonesian teachers in SMP / MTs. The third indicator, with the question whether the draft implementation of Indonesian language learning that has been prepared so far has facilitated productive texts and productive for the value, norms, and behavior of Indonesian, a number of $60 \%$ of respondents stated quite well and $40 \%$ of respondents expressed poor. This shows that the lesson design that has been prepared by Indonesian teachers has not facilitated the students' learning activities in producing texts on the one hand, and has not been maximal in providing cultural experience for students on the other. Thus, the required substantive materials are the steps to develop a good and correct learning plan, including (a) learning identity (b) KI, KD, and learning indicators, (c) learning objectives, (d) development of teaching and learning materials, (e) selection of learning resources, (f) development of learning media, (g) selection of learning models and techniques (h) learning scenarios, and (i) evaluation of learning.

The third indicator, with the question of whether students can learn Indonesian 
in accordance with the productive learning steps that have been designed so far a number of $70 \%$ of respondents stated quite well and $30 \%$ expressed less well. This can give an idea that the design of learning that is not fully adequate has an impact on student learning activities that are not adequate as well. Substantive materials required in the framework of mastery of teacher pedagogical competencies with regard to the implementation of learning plans include (a) apperception and motivational activities, the delivery of competencies and activity plans, (c) mastery of learning materials, (d) the application of educational learning strategies, (e) the application of scientific approaches, (f) the utilization of customs/media resources, (g) the involvement of students in learning, (h) the use of language, and (i) the closure/reflection of learning.

\section{SKPB Model Needs Publication of Research Results or Learning Ideas}

Two indicators of the need for the object of publication of research results or learning ideas include (1) the development of substantive mastery of the publication of simple research results of learning in the form of articles, and (2) the development of substantive mastery of the publication of scientific ideas of learning in the form of papers

On the first indicator, with the question of whether basic materials are needed publication of simple research results of Indonesian language-based language learning texts and Indonesian characters in the form of articles, a number of $60 \%$ of respondents stated indispensable and the other $40 \%$ stated quite necessary. The second indicator, with the question of whether basic material is needed for the publication of scientific ideas of Indonesian language-based text and Indonesian character in the form of papers, a number of $70 \%$ of respondents stated that it is necessary and the other $30 \%$ stated it is quite necessary. This indicates that the writing of scientific ideas is more necessary than article writing. However, formally the ability to write a teacher's scientific work is one component of the development of the teacher's profession and career. Therefore, although factually writing scientific work has not been cultivated among teachers, pedagogical competencies on this issue need to be mastered by Indonesian teachers in SMP / MTs. Mastery of the necessary teacher scientific work includes the truth of the content, methodological truth, and systematic truth.

\section{CONCLUSION}

Based on the description, it can be concluded five things as follows.

First, SKPB model on innovative learning model of Indonesian language teachers in SMP/MTs, covering the learning model of content delivery and classroom management. The innovative learning model SKBP draft developed includes (a) a model of delivery of learning content needed by teachers, including problem-based learning synths, project-based learning, and findings-based learning, and (b) a class management model covering contextual methods with various techniques and 
cooperative methods with various techniques including the regulation of both types of learning models in the implementation of learning with scientific approaches and the planting of Indonesian characters both through presented text materials and Indonesian language learning activities in the classroom. Second, the SKBP model on the creative learning media of Indonesian language teachers in SMP/MTs includes understanding, type, characteristics, development, and utilization of ICT-based media. SKPB draft creative learning media developed includes (a) planning, development, and utilization of integration of all learning components ranging from basic competencies, indicators, objectives, materials, learning steps according to model and engineering options, and evaluation in one creative media, and (b) Integration is carried out by utilizing various ICT software such as android, flash, $i$-spring, exe, etc.

Third, the SKBP model on adaptive learning evaluation of Indonesian teachers in SMP/MTs includes tests as instruments, scoring, and assessment. Draft SKPB adaptive learning evaluation developed includes (a) test instruments: form, type, and futuristic question items based on core competencies as well as basic knowledge and skills, (b) scoring includes the preparation of assessment rubrics and assessment weights, assessment includes determination of quantity and quality of process and learning outcomes and reporting in accordance with the minimum mastery criteria of each core competency / basis. Fourth, the SKBP model of the productive learning plan of Indonesian teachers in SMP/MTs includes the definitive conception of the learning design and various new terms according to the revised 2013 curriculum edition, the minimal component of the learning design, and the systematics of the learning design. The draft SKBG productive learning plan developed includes (a) eight steps to develop an Indonesian language learning plan and (b) 9 steps to implement an Indonesian language learning plan.

Fifth, the SKBP model on the writing of scientific works resulting from research or the idea of learning Indonesian teachers in SMP / MTs covers the truth of the content, methodological truth, and systematic truth. The SKBP draft of scientific writing developed includes (a) the type of scientific work of research-resulting articles: systematics of research-resulting articles, article writing techniques, and publication strategies through scientific journals, and (b) scientific works of paper type: systematic papers, paper writing techniques, techniques for composing paper presentations, and techniques of presenting papers in scientific forums. 
Volume 4 Number 2 December 2020

\section{REFERENCE}

Amri, Sofan, (2013) Pengembangan dan Model Pembelajaran dalam Kurikulum 2013. Jakarta: PT. Prestasi Pustakaraya.

Arief, Nur Fajar dan Tabrani, Ahmad. (2013) Kompetensi Metode dan Teknik Guru BI Berdasarkan Kurikulum 2013. Laporan Hasil Diklat: Tidak Diterbitkan. Malang: Universitas Islam Malang.

Arief, Nur Fajar dan Tabrani, Ahmad. (2013). Kompetensi Media Pembelajaran Berbasis ICT Guru BI Berdasarkan Kurikulum 2013. Laporan Hasil Diklat: Tidak Diterbitkan. Malang: Universitas Islam Malang.

Arief, Nur Fajar dan Tabrani, Ahmad. (2014) Kompetensi Evaluasi Pembelajaran Guru BI Berdasarkan Kurikulum 2013. Laporan Hasil Diklat: Tidak Diterbitkan. Malang: Universitas Islam Malang.

Arief, Nur Fajar dan Tabrani, Ahmad. (2015) Kompetensi Rancangan Pembelajaran Guru BI Berdasarkan Kurikulum 2013. Laporan Hasil Diklat: Tidak Diterbitkan. Malang: Universitas Islam Malang.

Brown, H. Douglas. (2007) Prinsip Pembelajaran dan Pengajaran Bahasa. USA: Pearson Education Inc.

Dickins, Paulene Rea dan Germaine, Kevin (2007) Evaluation. UK: Oxford University Press. Freeman, Diane Larsen. 1985. Techniques and Principles in Language Teaching. UK: Oxford University Press.

Kemendikbud. (2014) Panduan Pembelajaran Bahasa Indonesia Kurikulum 2013 Jakarta: Kementerian Pendidikan dan Kebudayaan.

Kemendikbud (2014) Bahasa Indonesia Wahana Pengetahuan: Buku Guru Kelas VIII SMP/MTs. Jakarta: Kementerian Pendidikan dan Kebudayaan.

Kemendikbud (2014) Bahasa Indonesia Wahana Pengetahuan: Buku Guru Siswa VIII SMP/MTs. Jakarta: Kementerian Pendidikan dan Kebudayaan.

Majid, Abdul (2013) Strategi Pembelajaran. Bandung: PT. Remaja Rosdakarya.

Richards, Jack C. dan Renandya, Willy A. (2002) Methodology in Language Teaching: An Anthology of Current Practice. UK: Cambrigde University Press.

Hedge, Tricia (2007) Teaching and Learning in the Language Classroom. UK: Oxford University Press.

Johnson, LouAnne. (2008) Pengajaran yang Kreatif dan Menarik. Jakarta: Direktorat Jenderal Peningkatan Mutu Pendidik dan tenaga Kependidikan Depdiknas. Tidak diperjualbelikan.

Kemmis \& Taggart (1988) The Action Research Planner. Geelong Victoria: Deakin University Press.

Majid, Abdul (2007) Perencanaan Pembelajaran: Mengembangkan Standar Kompetensi Guru. Bandung: PT. Remaja Rosdakarya.

Mulyasa, H.E. (2013) Pengembangan dan Implementasi Kurikulum 2013. Bandung. PT. Remaja Rosdakarya. 
Oxford, R. L. (1990). Language learning strategies: what every teacher should know. New York: Newbury House Publishers

Priatna, Nanang dan Sukamto, Tito. (2013) Pengembangan Profesi Guru. Bandung: PT. Remaja Rosdakarya.

Richards, Jack C. dan Rogers, Theodore S. (2001) Approches and Methods in Language

Teaching. UK: Cambridge University Press.

Rusman. (2012) Model-model Pembelajaran: Mengembangkan Profesionalisme Guru. Jakarta: Rajawali Press.

Samani, Mukhlas. (2012) Belajar dan Pembelajaran. Bandung: PT. Remaja Rosdakarya.

Trianto. (2012) Mendesain Model Pembelajaran Inovatif-Progresif. Jakarta: Kencana Prenada Media Grup.

Warsono dan Hariyanto. (2013) Pembelajaran Aktif: Teori dan Asesmen. Bandung: PT. Remaja Rosdakarya.

Zaini, Munthe, Bermawy, dan Aryani, Sekar Ayu. (2008) Strategi Pembelajaran Aktif. Yogyakarta: Pustaka Insan Madani. 